https://doi.org/10.15407/scin16.06.083

FESENKO, O.M., KORSKANOV, V.V., BUDNYK, O.P., and POGORETSKII, P.P. Institute of Physics, the NAS of Ukraine, 46, Nauky Ave., Kyiv, 03028, Ukraine, +380 $445259841,+38044525$ 1589, fizyka@iop.kiev.ua

\title{
MODERN LEVEL OF RESEARCH, INNOVATION, AND PATENT ACTIVITIES IN UKRAINE
}

Introduction. The development of patent and innovation is impossible without a strong scientific base. That is why the REDD potential of the state is one of the main factors that reflect the level of both economic and technical level of its development. Unfortunately, the level of patent innovation in Ukraine is low, despite the strong $R \& \mathcal{E} D$ potential.

Problem statement. The efficiency of innovations, trends in nanotechnology patenting, and the level of nanotechnology development in Ukraine are mainly determined by the qualifications of Ukrainian researchers. Therefore, preserving the RESD potential of Ukraine and preventing its outflow abroad are among the most pressing problems today.

Purpose. To determine the role of $R \mathcal{E} D$ in the economy of Ukraine and the world, the level of publications of Ukrainian authors, the effectiveness, patent circulation, and prospects of innovations in Ukraine. To characterize the world market of nanotechnologies and the level of development of nanotechnologies in Ukraine and to provide a forecast of innovative development in Ukraine and the world.

Materials and Methods. Statistical data of REDD potential of Ukraine, number of research works in Ukraine, materials on the quantitative and qualitative level of scholarly research publications of Ukrainian authors, patent circulation, the efficiency of innovations in Ukraine for the period 2010-2017, for forecasting of innovative development in Ukraine and the world on the coming decades.

Results. The REDD potential of Ukraine, the current level of nanotechnology, innovation, and trends in their further development have been evaluated. The innovative development in Ukraine and the world until 2030 has been forecasted.

Conclusions. Ukraine has a strong REDD potential, but the level of patent and innovation activity in Ukraine is low. Against the background of the integration of Ukrainian researchers into the world community, there is a significant increase in the number of joint scholarly research publications of Ukrainian researchers with foreign colleagues.

Keywords: innovation activity, patents, nanotechnology, research work.

The development of patent and innovation activities is not possible without a strong $R \& D$ base. That is why the $R \& D$ potential of each country is one of the main factors that reflect the level of both economic and technical level of its development. The notions of patent business, innovation and the level of transfer of nanotechnology are interconnected. Since

Цитування: Fesenko O.M., Korskanov V.V., Budnyk O.P., and Pogoretskii P.P. Modern Level of Research, Innovation, and Patent Activities in Ukraine. Nauka innov. 2020. V. 16, no. 6. P. 83-94. https://doi. org $/ 10.15407 / \operatorname{scin} 16.06 .083$ 
a patent is the result of the intellectual activity of a person in any sphere of technology, patent activity depends directly on the $R \& D$ potential of the country and determines the level of technological development [1]. Unfortunately, in Ukraine, the level of patent and innovation activity is low, despite the powerful $R \& D$ potential. The main reason for this is the low percentage of Gross Domestic Product (GDP) spent on financing the research works. In Ukraine, this percentage in 2017 was 0.45 . While in advanced economies it reaches 5.0. The other is the potential reluctance of managers of enterprises to innovate in order not to disrupt the production process, since the manager personally is not interested in increasing the efficiency of production. Another reason is that in some research institutes, research projects are sometimes up to $90 \%$ funded by the Ministry of Defense. And this means that the results of the research works and the associated patents are automatically considered to be closed.

\section{R\&D POTENTIAL OF UKRAINE, ITS PERSONNEL, QUANTITATIVE AND QUALITATIVE COMPOSITION}

The $R \& D$ potential of Ukraine is concentrated in three main sectors: academic, branch, and university [2].

As of January 1, 2017, there were 661 higher educational establishments (universities) in Ukraine. Training of $3^{\text {rd }}$ and $4^{\text {th }}$ level accreditation is carried out by 289 universities, academies and ins- titutes. At the beginning of the 2018/19 school year, 652 higher educational institutions operated in Ukraine, which is nine less than in 2017 [3]. Of the 107.8 thousand $R \& D$ and pedagogical workers of universities, academies, institutes, almost $57 \%$ - Ph.D. (candidates of sciences); $12.6 \%$ doctors of sciences. More than 1.340 thousand students study at higher educational institutions simultaneously. Including 127 thousand bachelors and 80 thousand masters. There are 475 institutions in the country in which post-graduate students are trained, of which 231 are universities and 277 institutions, in which doctoral studies are in progress, of which 176 are universities. Unfortunately, due to the economic crisis, the number of postgraduate students and doctoral students in recent years is rapidly decreasing. For the same reason, and due to the more than $50 \%$ reduction in funding for the period from 2010 to 2017, the staff of the research institute and the number of research works and development works (R\&Ds) that were spent over the same period of time have decreased more than twice (Table 1). If in the midlate 1990s-2000s the decrease in the number of post-graduate students and doctoral students in Ukraine was due to the removal of young people to the business, then in recent years this decline is conditioned by the desire of young graduates to enter post-graduate or doctoral studies in Western Europe or other advanced economies. Improving the quality of education in Ukrainian universities has led to an unexpected result: the out-

Table 1. The Number and Quality of Researchers and R\&D in Ukraine

\begin{tabular}{|c|c|c|c|c|c|c|c|c|}
\hline \multirow{2}{*}{ Researchers and part from GDP } & \multicolumn{8}{|c|}{ Years } \\
\hline & 2010 & 2011 & 2012 & 2013 & 2014 & 2015 & 2016 & 2017 \\
\hline Postgraduate training, persons & 34653 & - & - & 30740 & 27622 & 28487 & 25963 & 24786 \\
\hline Doctoral training, persons & 1532 & - & - & 1795 & 1759 & 1821 & 1792 & 1646 \\
\hline Research costs, \% GDP & 0.75 & 0.65 & 0.67 & 0.70 & 0.60 & 0.55 & 0.48 & 0.45 \\
\hline The state costs, \% GDP & 0.33 & 0.29 & 0.33 & 0.32 & 0.25 & 0.20 & 0.16 & 0.16 \\
\hline $\begin{array}{l}\text { Researchers in research organizations, } \\
\text { thousand individuals }\end{array}$ & 133.7 & 130.4 & 122.1 & 115.8 & 101.4 & 90.2 & 63.7 & 59.4 \\
\hline $\begin{array}{l}\text { Personnel in research organizations, } \\
\text { thousand individuals }\end{array}$ & 182.5 & 175.3 & 164.3 & 155.4 & 136.1 & 122.5 & 97.9 & 94.3 \\
\hline
\end{tabular}


flow of young specialists abroad has increased, due to the fact that the graduate, having received a high-quality education in Ukraine, finds it easier to find work abroad.

Not the last factor of the low level of development of patent and innovation activity in $R \& D$ institutions of Ukraine is the lack of a single center for marketing and management of $R \& D$ activity. This leads to the fact that the majority of registered patents and innovations are not implemented. It is not uncommon that R\&Ds in different research institutes overlap, or even duplicate each other. Instead, research is conducted in isolation from the needs of the economy.

\section{THE PHASE AND ROLE OF THE SCHOLARLY RESEARCH IN THE ECONOMY OF UKRAINE}

The underfunding the R\&D, accompanied by an annual decrease in the share of GDP to finance the RW, against the backdrop of a general reduction in GDP associated with the economic crisis, has led to a significant reduction in the number of research works and staff of the Research Institutes in Ukraine as a whole. Another reason for this is the outdated and the fact that the research equipment has exhausted its resources. Measuring and experimental equipment was manufactured during the USSR, and now there are no funds to buy new ones. At the beginning of this decade, attempts were made to improve this situation by creating centers for collective use and the acquisition of new experimental equipment in research institutes. However, this did not fundamentally change the situation [4].

The degree of interest of the government in the introduction of new technologies can be expressed in the ratio of funds invested in the $R \& D$ to the total GDP (Fig. 1).

It is believed that for normal functioning of the economy, the country should spend at least one percent of GDP on own R\&D. The countries in which this percentage is lower are classified as countries with a poorly developed economy. If the share of expenditures for the implementation of $\mathrm{R} \& \mathrm{D}$ exceeds 2 per cent, then this country is
Share of R\&D expenditure in the world $2017, \%$ of GDP

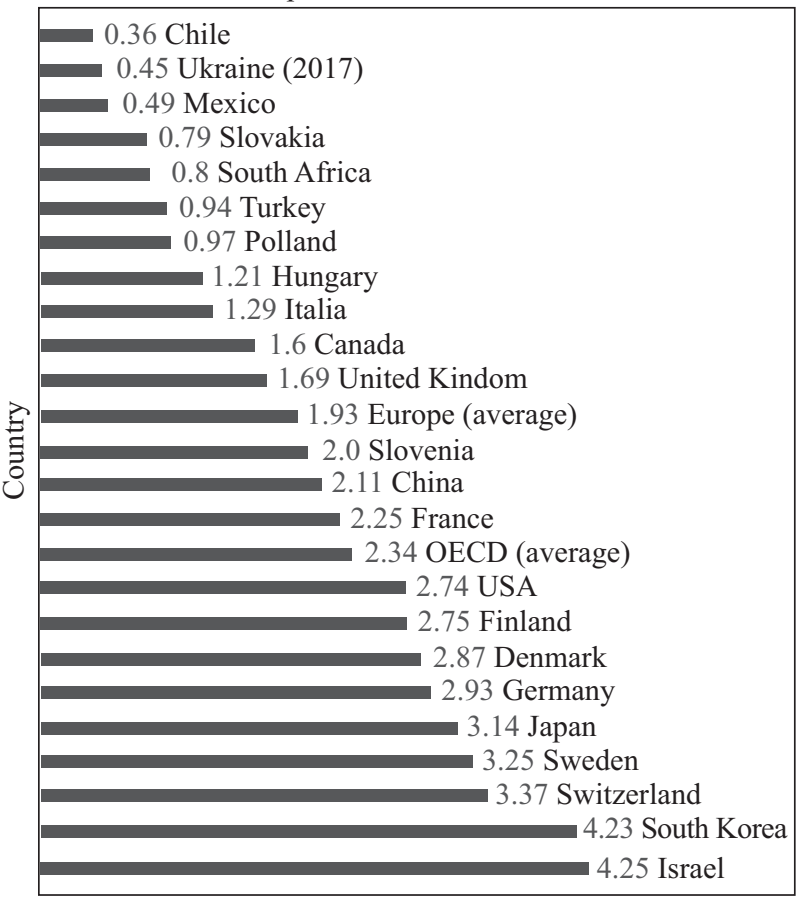

Fig. 1. Share of R\&D expenditure in the world, \% of GDP [5]

classified as a country with high development. From the chart higher, it is clear that among the 25 countries Ukraine occupies the penultimate position, ahead of only high-mountainous Chile. The highest places in this indicator are high-growth countries - Switzerland, Israel, South Korea, Japan, Sweden, Germany, Denmark, Finland and the USA.

Fig. 2 shows the distribution of research works in Ukraine for the period from 2013 to 2017 on new types of products, technologies, materials, methods and theories. In recent years, a large proportion of methodological and theoretical research in comparison with experimental ones is the result of the insufficiently powerful material and technical base of Ukrainian research institutes. The smallest part of the research work is the work on the development of new types of products, which leads to an unsatisfactory range of Ukrainian products. Much more in Ukraine is paid attention to the development of new innovative energy-saving technologies. This, in par- 


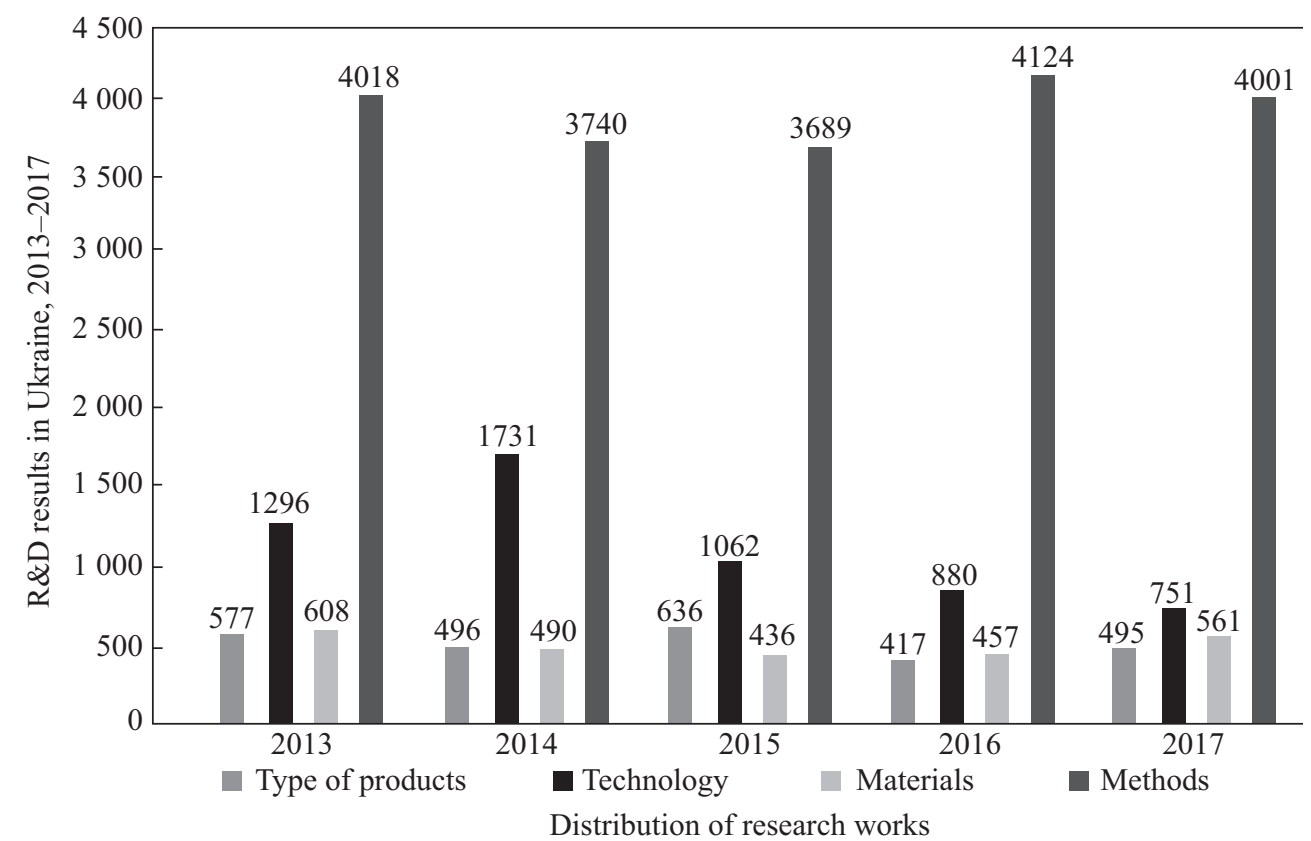

Fig. 2. R\&D results in Ukraine, 2013-2017

ticular, has contributed to the rapid rise in energy prices over the past 5 years. The development of new technologies is central to the experimental research work, but after 2014 the number of technological developments is decreasing. Probably this is due to the redistribution of funds to the defense department regarding events in the East of Ukraine.

In recent years, there has been a slight increase in attention to the development and production of new promising materials in Ukraine. Economic analysis has shown that it is much more profitable to produce materials or products in Ukraine, rather than importing raw materials or semi-finished products. On the other hand, it will create additional jobs and prevent the outflow of workers abroad. However, on the ground, managers of enterprises consider it expedient to import raw materials and buy ready-made materials, while receiving a refund of value added tax. This is what inhibits work related to the development of their own innovative materials.

On average, the ratio of experimental to theoretical $\mathrm{R} \& \mathrm{D}$ works during these years is 0.56 , but over time, decreases slightly from 0.60 to 0.45 .

\section{QUANTITATIVE AND QUALITATIVE LEVEL OF THE SCHOLARLY RESEARCH PUBLICATIONS BY UKRAINIAN AUTHORS}

Until the beginning of the 2000s, it was very problematic for Ukrainian scholars to access information and literary sources from foreign information platforms. Ukrainian information platforms were either imperfect, or, in some areas, in general, they were absent. After the 2000s was some breakthrough in this direction and today it is quite easy to obtain the necessary information from sources of free access. Therefore, in recent years the level and quality of scholarly research publications of Ukrainian scholars have grown rapidly [6].

Fig. 3 provides a comparative diagram of the types of publications in the form of monographs, scholarly research articles and textbooks, textbooks and books for the period from 2015 to 2017. As expected, the number of scholarly research articles significantly exceeds (30-40 times) the number of monographs and the number of trained teaching aids. To a certain extent, this is natural, since the volume of a scholarly research article is much smaller than a monograph, a textbook, or a 
tutorial. To write a monograph, one must also select more than one dozen articles in the same direction and must combine the material in one logical chain. Some materials (examples, tests, tasks, checklist questions, etc.) should also be included in writing tutorials or textbooks.

The given diagram illustrates that for the last three years the number of scholarly research articles is decreasing. The number of monographs and textbooks over the years remains stable.

The quality of published works in the world is usually estimated by the index of citation ( $h$-index). From Fig. 4 it is evident that the index of Ukrainian authors' citation is almost 10 times lower than that of US researchers, 5 times smaller than that of German authors, three times than of Chinese, two times then of Indian, lower than that of Chilean scholars, and only slightly higher than estimating the work of the Belarussian authors. This situation proves, first of all, that Ukrainian researchers have long been isolated from access to relevant R\&D information and could not understand the perspective directions of the development of world science. On the other hand, for certain areas of scholarly research have was established the status of various secrecy, thus denying the possibility for researchers from other countries to receive information about these studies with the aim of further possible proceedings

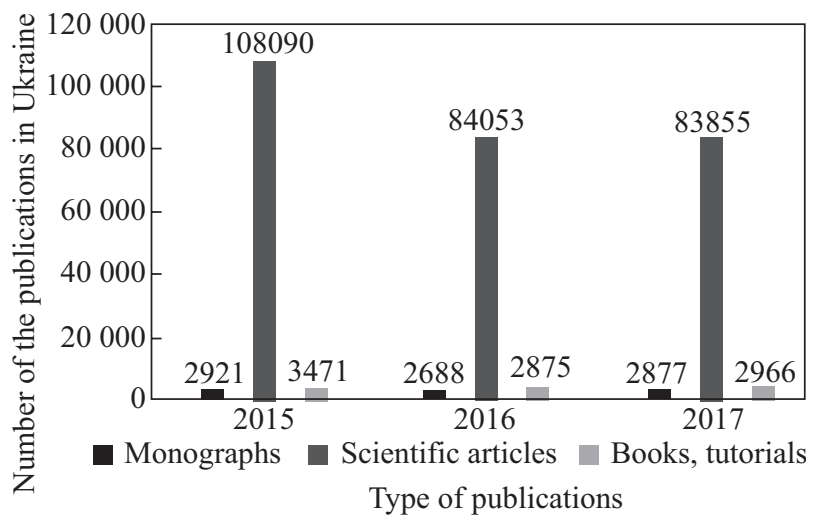

Fig. 3. Number of scholarly research publications in Ukraine, 2015-2017

and quoting. All scholarly research publications, which are fully or partly related to them, may not be allowed to be publicly disclosed, since they contain prohibited information.

According to Scopus, the results of 2017, most of the works were published in the field of physics and astronomy (3000), less - in materials science, mathematics, agriculture, biology, energy, planetology, and environmental science, respectively (Fig. 5).

Such a schedule of priorities, in the first place, indicates a rather powerful physics and mathematics school of Ukrainian science (physics, materials science, mathematics) [7]. At the same time, in the presence of large agricultural land in

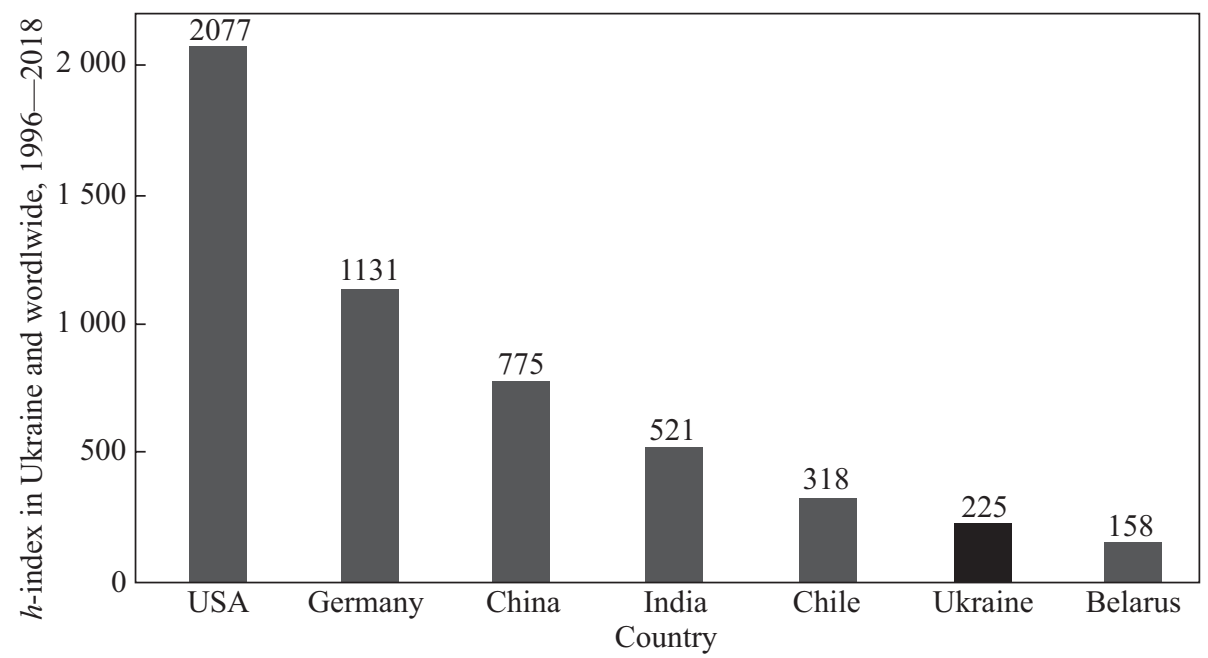

Fig. 4. $h$-index in Ukraine and wordlwide, 1996-2018 


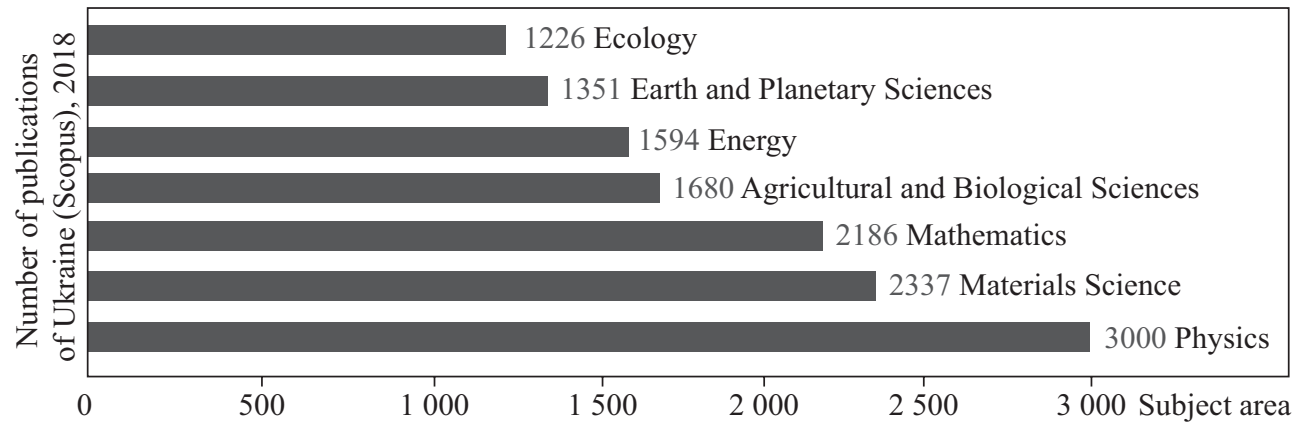

Fig. 5. The number of scholarly research publications of Ukraine by subject areas (according to Scopus), 2017.

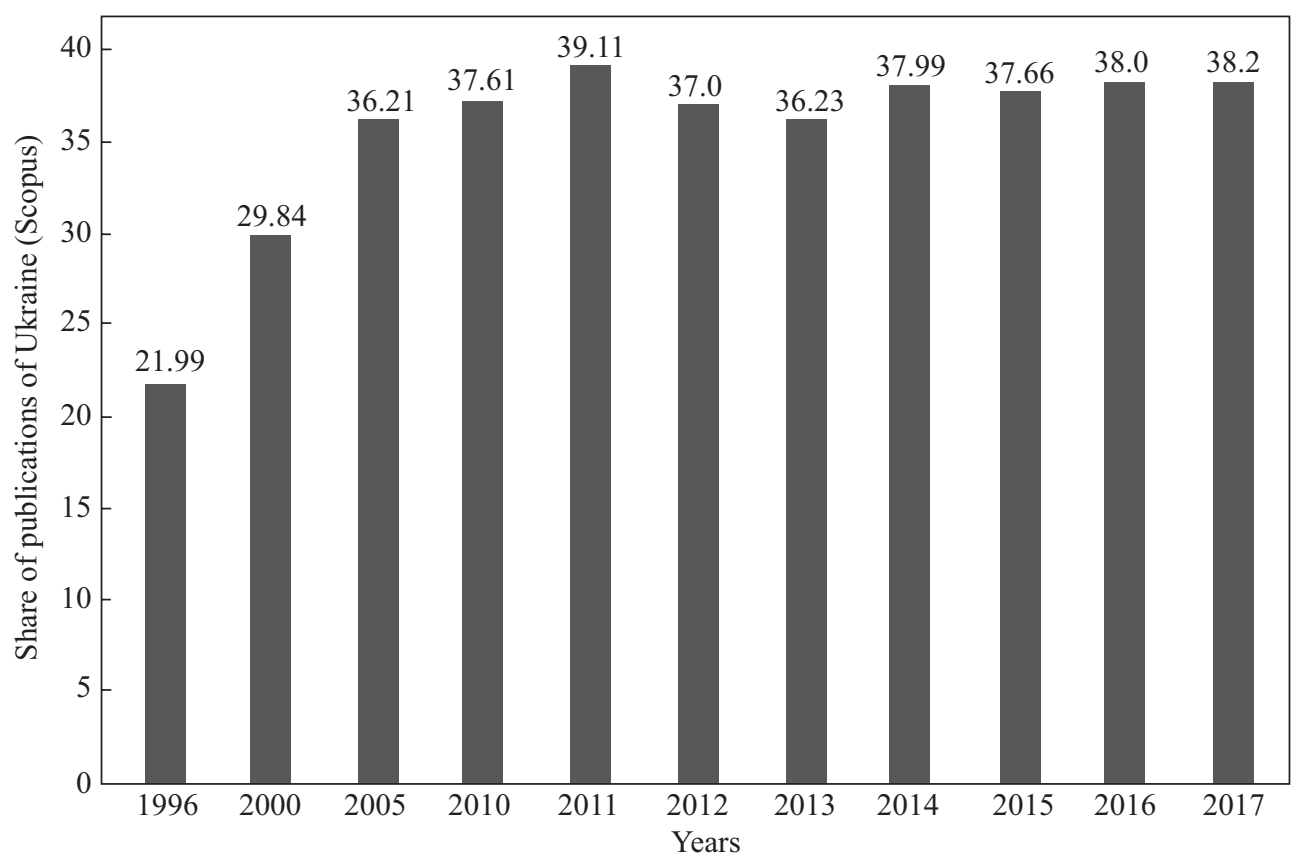

Fig. 6. Share of international scholarly research publications of Ukraine (according to Scopus)

Ukraine, insufficient attention is paid to the development of own technologies of land cultivation, land use culture, agronomy and the development of own fertilizers and obtain the biomasses for production the biofuel. Instead, agrarians buy fertilizers, land care products abroad, and import foreign technology for land cultivation, and obtain new fertilizers that have not even been tested in Ukraine [8].

Having enormous own reserves of restorative bioresources almost no attention is paid to the problem of their processing and processing. In- stead, in 2017-2018, the massive influx of foreign patented innovative technologies of biomass processing into biofuels and biomass into Ukraine was recorded [9-11]. The same applies to the problematic issue of energy. In the presence of bioresources, almost no attention is paid to the design and construction of mini-boilers on solid biofuels. Not even taking into account the fact that charcoal and ash are a valuable fertilizer for many plants. In Ukraine there is a shortage of boilers operating on combustion of peat. Instead, almost every year peatlands ignite and damage the envi- 
ronment. It should also be noted that with a sufficiently strong woodworking industry, the processing of wood waste, for example, for the production of briquettes for heating residential houses, is not established at all.

Against the background of the integration of Ukrainian scholars into the world community from 1996 to 2010, there was a marked increase in the number of joint scholarly research publications of Ukrainian scholars with foreign colleagues from $22 \%$ to $38 \%$ of the total number of publications (Fig. 6). Beginning from 2011 and till now, this figure remains constant. This testifies to the fact that relatively stable international R\&D groups with a certain share of contributions to joint publications have been formed at that time.

\section{EFFICIENCY OF INNOVATIONS IN UKRAINE, PATENT ACTIVITY AND PROSPECTS FOR THEIR IMPROVEMENT}

The analysis of the dynamics of expenditures of industrial enterprises for innovations showed that during 2010-2017 these expenditures were approximately constant and amount to an average of 7130.5 million UAH. During 2010-2013, the level of industrial enterprises' expenditures on innovation programs remained roughly constant at an average of UAH 9300 per year (Fig. 7). Then there was a substantial and gradual increase in these expenditures from about UAH 8300 million in 2013 up to 12.000 million UAH in 2016 Analysts attribute this to the growing need of enterprises of the military-industrial complex in advanced innovative technologies to connect with events in the East of Ukraine. In 2017, industrial enterprises spent on innovation 9117.5 million UAH, which is $60.8 \%$ less than in 2016 (Fig. 7).

The measure of effectiveness can be considered the number of patents received for inventions. Unfortunately, for the period from 2010 to 2017, their number is steadily decreasing both in Ukraine and abroad in general. At the same time, their ratio practically does not change (Fig. 8).

According to statistics, the number of patents registered in Ukraine by Ukrainian inventors significantly exceeds the number of Ukrainian patents obtained in the United States, Western Europe, Japan, China, and others (Fig. 9). This is logical, since most of the Ukrpatent's inventions, or utility models, are associated with the daily lives of Ukrainians.

The largest number of patents of Ukrainian inventors outside Ukraine is registered in the United States (55\% of the number of patents in Ukraine). Less in Germany $-14 \%$ of the number of patents in Ukraine. For other countries, these numbers decrease as shown in the diagram (Fig. 9).

In general, in Europe, the share of Ukrainian patents is $54 \%$ - almost as much as in the United

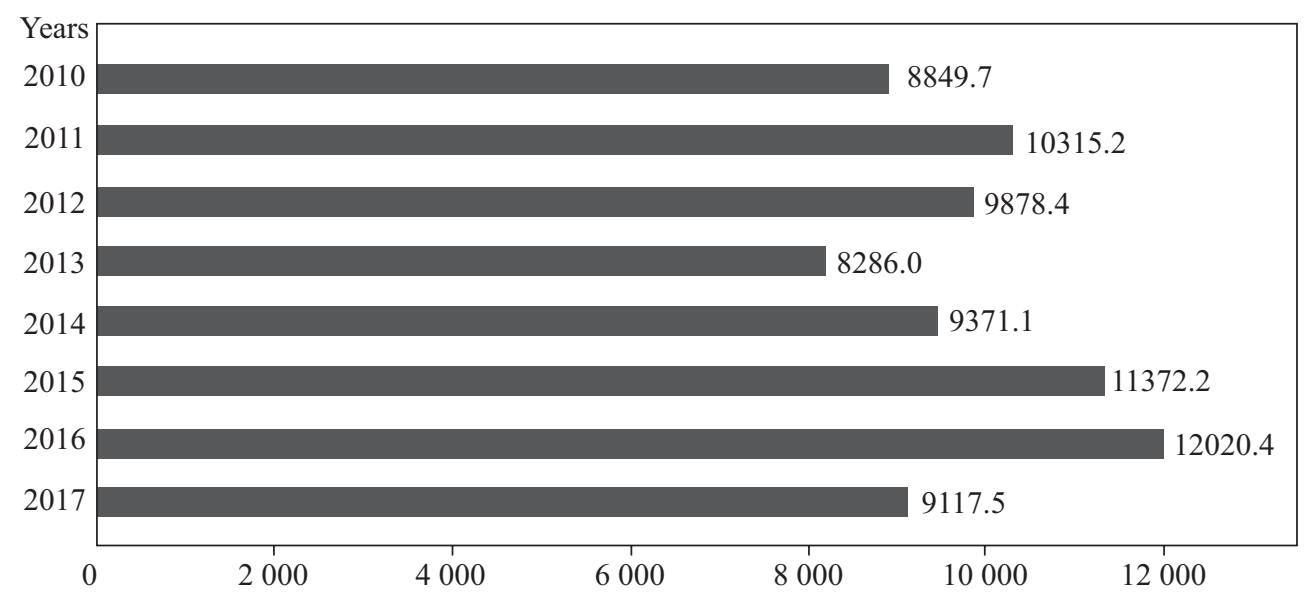

Fig. 7. Expenses of enterprises for innovation activity in Ukraine by years, millions of UAH 


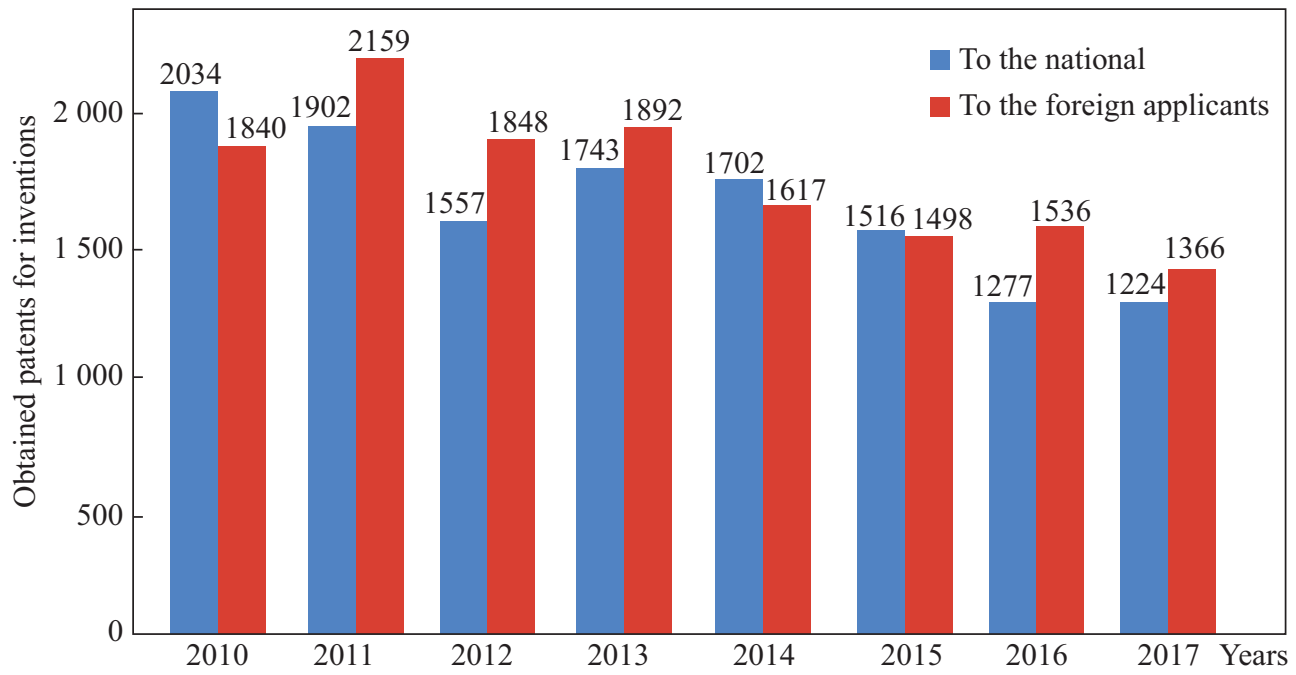

Fig. 8. Obtained patents for inventions: blue - to the national applicants; red - to the foreign applicants

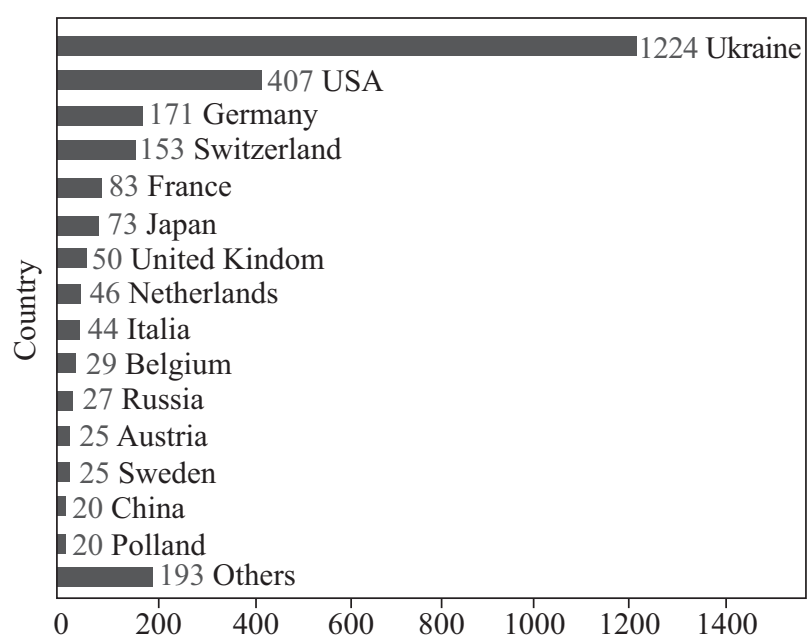

Fig. 9. Number of registered patents for inventions in Ukraine and worldwide, 2017

States. The given diagram is indicative and does not reflect the actual picture of the introduction of these patent inventions into the economy [12].

According to the technical branches by sections in 2017, the chemical industry is the undisputed leader, followed by engineering, tools, electrical engineering, and others [13].

In 2017, in Ukraine, innovations were implemented at 672 enterprises; 456 enterprises introduced new technological processes, 358 companies designed innovative products. However, in

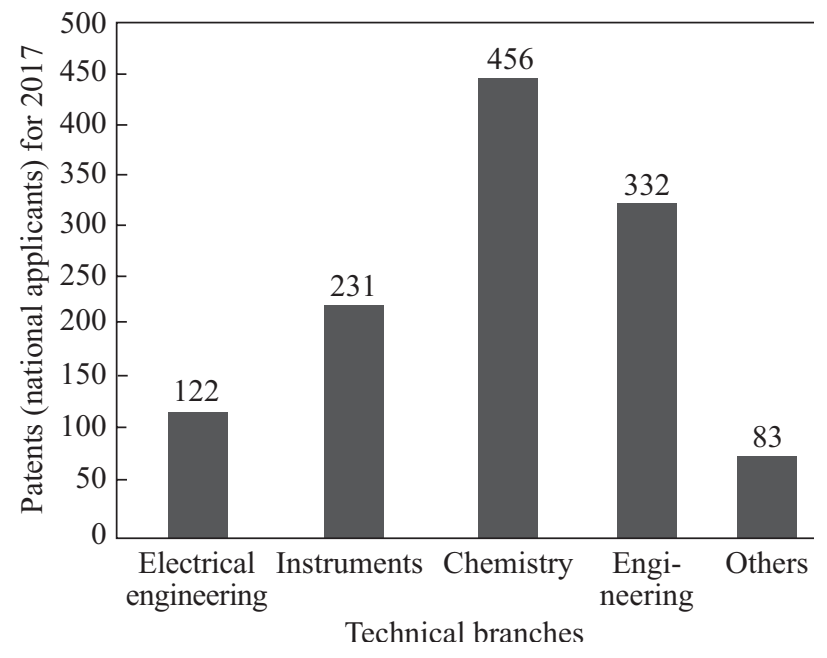

Fig. 10. Patents for inventions by technical branches (national applicants) for 2017

comparison with previous years, these figures look very unconvincing (Table 2 ).

One of the main conditions for a competitive country is the formation and operation of innovative infrastructure. Currently, there are a large number of organizations that promote innovation in Ukraine. The innovative infrastructure of Ukraine includes 25 scientific and 16 technological parks, its own venture fund, 38 centers for IT commercialization, 108 technology transfer centers 
at universities, 22 innovation centers, 24 business incubators, 834 innovative enterprises, and 263 other innovative structures [13]. Ukraine's Global Innovation Index grew by 7 positions and in 2018 and ranked $43^{\text {rd }}$ among the 126 countries that participated in the study. According to the index of global competitiveness, Ukraine in 2018 ranks $83^{\text {rd }}$ in the ranking among 140 countries. According to the index of business, as of the beginning of 2019, Ukraine improved this indicator by 5 points per year and ranked $71^{\text {st }}$ among 190 countries.

\section{THE CURRENT LEVEL OF DEVELOPMENT OF NANOTECHNOLOGIES AND TRENDS IN PATENTING OF NANOTECHNOLOGIES}

The revolutionary impact of nanoscience and nanotechnology $(\mathrm{N} \& \mathrm{~N})$ on all areas of modern human civilization was foreseen in 2005 in the journal Science. Currently, researchers are offering powerful nano-tools in this area, which can improve the properties of materials, obtain new nanomaterials and methods of analysis of nanoscience. On the other hand, basic (nanoscience) and applied (nanotechnology) developments and achievements require information on nanoscale space to carry out their tasks and to make informed and timely decisions. Revolution in the development of measuring instruments in the $20^{\text {th }}$ century (for example, $\mathrm{pH}$ meters, potentiometers, nanovoltmeters and nanoammeters, photometers, fluorimeters, calorimeters, gas and liquid chromatographs, X-ray spectrometers) from the middle of the $21^{\text {st }}$ century was indisputable. The second stage in the evolution of analytical science in the transition between the twentieth and twenty centuries was the use of computers to improve analytical processes by supporting automation, miniaturization, simplification, and implementation of quality systems, as well as data processing.

According to the generally accepted definition, nanoscience is a discipline that studies a substance in a size that is, in at least one dimension is from 1 to 100 nanometers. Nanotechnology-concept is very broad and includes such branches of science as science of the earth, organic chemistry, molecular biology, physics of semiconductors, etc. [14]. New approaches in nanotechnology are based on molecular self-organization, from the development of new materials with nanoscale dimensions to the direct control of matter at the atomic level. The International Patent Classification (IPC) in the field of patents for nanomaterials contains 70,000 applications. The Total $\mathrm{Pa}-$ tent Classification (TPC) consists of 250,000 applications [15]. As examples, it is the production of carbon nanomaterials, computer systems based on biological objects (including biomolecular computers), nanosized semiconductor devices, etc [16]. Other classic examples of nanotechnology and their number are given in Table 3.

In the field of clean or green energy, in 2015, there were 14700 applications and there is a rapid increase from year to year.

The United States Patent and Trademark Office (USPTO) and the European Patent Office (EPO) are the two most influential patent offices in the world. Statistics from OrbitDatabase showed

Table 2. Innovative Products and New Technological Processes Introduced

\begin{tabular}{|l|c|c|c|c|c|c|}
\hline \multicolumn{1}{|c|}{ Innovative products } & \multicolumn{4}{c|}{ Years } \\
\cline { 2 - 7 } & 2012 & 2013 & 2014 & 2015 & 2016 & 2017 \\
\hline Introduced innovative products & 3403 & 3138 & 3661 & 3136 & 4139 & 2387 \\
Including cars, equipment, devices & 942 & 809 & 1314 & 966 & 1305 & 751 \\
The new technological processes, units & 672 & 640 & 540 & 548 & 978 \\
Introduced technological processes & 2188 & 1576 & 1743 & 1217 & 3489 & 1831 \\
Low-waste, resource-saving, non-waste & 554 & 502 & 447 & 458 & 748 & 611 \\
\hline
\end{tabular}


that 19563 patents for nanotechnology were published in 2016, among which 8484 received patents and 11079 published patent applications [18]. According to StatNano, in 2016, a total of 19563 patents for nanotechnology were published in the USPTO. In total, 3589 patents for nanotechnology were issued in 2016 and published in the EPO. According to the new StatNano definition

Table 3. Examples of the Most Widespread Nanotechnologies

\begin{tabular}{|c|c|}
\hline Name & $\begin{array}{l}\text { Quantity, } \\
\text { documents }\end{array}$ \\
\hline Nanobiotechnology or nano-medicine & 30000 \\
\hline $\begin{array}{l}\text { Nanotechnology for information processing, } \\
\text { storage, and transmission }\end{array}$ & 70000 \\
\hline $\begin{array}{l}\text { Nanotechnology for interacting, sensing, and } \\
\text { actuating }\end{array}$ & 12000 \\
\hline Nanotechnology for optics & 37000 \\
\hline Nanomagnetism & 23000 \\
\hline $\begin{array}{l}\text { Nanotechnology for materials and surface } \\
\text { science }\end{array}$ & 88000 \\
\hline $\begin{array}{l}\text { Methods or apparatus for measurement or } \\
\text { analysis of nanostructures }\end{array}$ & 11000 \\
\hline Manufacture or treatment of nanostructures & 41000 \\
\hline
\end{tabular}

In total nearly 240000 documents classified as nanotechnology.

Table 4. Top Ten Countries for the Patents in 2017

\begin{tabular}{|l|c|c|c|c|}
\hline Country & $\begin{array}{c}\text { Patents } \\
\text { in nano- } \\
\text { techno- } \\
\text { logy at } \\
\text { USPT }\end{array}$ & $\begin{array}{c}\text { Patents } \\
\text { on nano- } \\
\text { technology } \\
\text { in the } \\
\text { EPO }\end{array}$ & $\begin{array}{c}\text { Applica- } \\
\text { tions for } \\
\text { nanotech- } \\
\text { nology in } \\
\text { USPT }\end{array}$ & $\begin{array}{c}\text { Applica- } \\
\text { tions for } \\
\text { nanotech- } \\
\text { nology in } \\
\text { the EPO }\end{array}$ \\
\hline USA & 4316 & 577 & 5635 & 282 \\
South & 914 & 105 & 1326 & 273 \\
Korea & 819 & 188 & 805 & 268 \\
Japan & 514 & 19 & 591 & 97 \\
Taiwan & 416 & 59 & 566 & 25 \\
China & 301 & 289 & 413 & 165 \\
Germany & 210 & 208 & 284 & 92 \\
France & 136 & 71 & 196 & 8 \\
Netherland & 123 & 81 & 187 & 47 \\
United & 106 & 22 & 132 & 47 \\
Kindom & 123 & & \\
Canada & 106 & & \\
\hline
\end{tabular}

based on ISO / TS 18110, nanotechnology patents must either have at least one nanotechnology characteristic or have a classification code related to nanotechnology in accordance with the International Patent Classification (IPC). On the basis of this definition, there are 3589 patents published in the field of nanotechnology in the EPO in 2016 , about $18 \%$ of the total number of nanotechnology patents published in the USPTO. 2006 patents were received, and 1583 patent applications were issued. Countries were ranked by the number of patents granted.

The United States ranks first, with a share of over $50 \%$ of all nanotechnology patents in the USPTO. South Korea and Japan occupy the second and third places with a great lag behind the United States. StatNano shows that in this ranking, South Korea in 2016 ahead of Japan, Canada, and other countries.

Table 4 shows the top 10 countries in the world and the number of published applications for nanotechnology patents.

\section{STRATEGY OF INNOVATION DEVELOPMENT TILL 2030}

The intensive growth of patent and innovation activity in Ukraine in the near future is expected. The main goal is to provide a quick and qualitative transformation of creative ideas into innovative products and services that increase the level of innovation of the national economy.

Expected results of patent and innovation activities:

- reduction of the share of extra-budgetary financing of R \& D;

- inhibition of the trend of reducing the number of researchers;

- wider use of intellectual property objects;

- an increase in the number of entities that provide services for the commercialization of technological solutions;

- annual increase in the number of patents for inventions and utility models;

- increase in the share of expenses of the intangible assets. 


\section{CONCLUSIONS}

Ukraine has maintained a rather powerful $R \& D$ potential, but the level of patent and innovation activity in Ukraine is low, as the state spends a small percentage of GDP to carry out the R\&D.

In recent years, the number of research workers and research staff has been rapidly diminishing due to chronic under-funding and out-ofdate experimental equipment in the research institutes. For this reason, the index of citing the work of Ukrainian scholars is low. The weak material base of Ukrainian research institutes determines that the ratio of experimental to theoretical $R \& D$ projects in recent years is decreasing.

Most patents are registered by Ukrainian researchers in Ukraine in Ukrpatent. Ukrainians receive the largest number of international patents in the US, Germany, and Switzerland.

Against the background of the integration of Ukrainian scholars into the world community, there is a significant increase in the number of joint scholarly research publications of Ukrainian scholars with foreign colleagues.

Thus, in the future, for the development of patent and innovative activity in Ukraine, further integration of Ukrainian researchers into the international research community is necessary.

Acknowledgment: This work was carried in frames of the RE्FD project №78/19-H Creating an Innovative Information Environment to Support the Development and Commercialization of Nanotechnology in Ukraine.

\section{REFERENCES}

1. Kishi, K. (2019). Technology diffusion, innovation size, and patent policy. European Economic Revier, 118, 382-410. doi: https://doi.org/10.1016/j.euroecorev.2019.05.012

2. Scientific potential: essence, structure, dynamics. Regional Economics: Textbook. (2008). Ternopil [in Ukrainian].

3. Ukraine has reduced the number of universities and students. URL: https://www.rbc.ua/rus/news/ukraine-sokratiloskolichestvo-vuzov-studentov-1545898988.html (Last accessed: 29.07.2019).

4. Organization of research in Ukraine. URL: https://studfiles.net/preview/6696568/ (Last accessed: 29.07.2019).

5. Concentration of world scientific and technical resources in different countries and regions. URL: https://studme.com. ua/189808266895/ekonomika/kontsentratsiya_mirovyh_nauchno-tehnicheskih_resursov (Last accessed: 29.07.2019).

6. Scientific publications and publishing activities of the National Academy of Sciences of Ukraine. URL: http://www.nas. gov.ua/publications/Pages/default.aspx (Last accessed: 29.07.2019).

7. All Ukrainian journals in Scopus and Web of Science. URL: https://openscience.in.ua/ua-journals (Last accessed: 29.07.2019).

8. Canada patent WO 2016|183685, 24.11.2016 PCT|CA 2016|050569. Satish I., Sulvaris Inc. Canada. Fertilizer Pellets with Micronized sulfur.

9. Gollakota, A. R. K., Kishore, N., Gu, S. (2018). A review on hydrothermal liquefaction of biomass. Renewable and Sustainable Energy Reviewes, 81, 1378-1392. doi: https://doi.org/10.1016/j.rser.2017.05.178

10. Patent USA № 20180142157. (2014). Lin K., Li L., Guo L., Cui Y., Jiang L. Composition for Biomass Oil, and Preparation Method and Use thereof.

11. Patent USA US20180142157, № publ. 20180142157, Date publ. 24.05.2018. Lin K., Li L., Guo L., Cui Y., Jiang L. Composition for Biomass Oil, and Preparation Method and Use Thereof.

12. Descriptions of Ukrainian patents for inventions and utility models. URL: http://www.uipv.org/ua/opisi_patentiv.html (Last accessed: 29.07.2019).

13. Innovative Infrastructure of Ukraine: Problems and Prospects of Development. URL: http://investycii.org/investuvanya/konferentsiji/problemy-formuvanya-ta-rozvytku-inovatsijnoji-infrastruktury/inovatsijna-infrastruktura-ukrajiny-problemy-ta-perspektyvy-rozvytku (Last accessed: 29.07.2019).

14. Soriano, M. L., Zougagh, M., Valcárceld, M., Ríose, Á. (2018). Analytical Nanoscience and Nanotechnology: Where we are and where we are heading. Talanta, 177, 104-121.

15. Nikos, B., Varsakelis, C. (2017). International patenting: An application of network analysis. The Journal of Economic Asymmetries, 15, 48-55.

16. Gupta, R. K., Dwivedy, I. (2005). International patenting activity in the field of carbon nanotubes. Current Applied Physics, 5(2), 163-170. 
17. Mezzanotti, F., Simcoe, T. (2019). Patent policy and American innovation after eBay: An empirical examination. Research Policy, 48(5), 1271-1281. doi: https://doi.org/10.1016/j.respol.2019.01.004

18. Ferrucci, E., Lissoni, F. (2019). Foreign inventors in Europe and the United States: Diversity and Patent Quality. Research Policy, 48(9), 103774. doi: https://doi.org/10.1016/j.respol.2019.03.019

19. Jamasb, T., Pollitt, M.G. (2019). Electricity sector liberalisation and innovation: An analysis of the UK's patenting activities. Research Policy, 40(2), 309-324. doi: https://doi.org/10.1016/j.respol.2010.10.010

20. Nikzad, R. (2014). Canadian worldwide patent activity: An industrial level analysis. World Patent Information, 38, 1218. doi: https://doi.org/10.1016/j.wpi.2014.03.001

21. Dereli, T., Durmuşoğlu, A. (2009). Patenting activities in Turkey: The case of the textile industry. World Patent Information, 31(2), 123-130. doi: https://doi.org/10.1016/j.wpi.2008.07.003.

Стаття надійшла до редакції / Received 05.08.19

Статтю прорецензовано / Revised 19.09.19

Статтю підписано до друку / Accepted 07.11.19

Фесенко О.М., Корсканов В.В., Будник О.П., Погорецький П.П.

Інститут фізики НАН України,

просп. Науки, 46, Київ, 03028, Україна,

+38044525 9841, +380 44525 1589, fizyka@iop.kiev.ua

\section{СУЧАСНИЙ РІВЕНЬ НАУКОВОЇ, ІННОВАЦІЙНОЇ \\ ТА ПАТЕНТНОЇ ДІЯЛЬНОСТІ В УКРАЇНІ}

Вступ. Розвиток патентної та інноваційної діяльності неможливий без потужної наукової бази. Саме тому науковий потенціал держави є одним з основних факторів, що відображає рівень як економічного, так і технічного рівня іiі розвитку. На жаль, в Україні рівень патентно-інноваційної діяльності є низьким, незважаючи на потужний науковий потенціал.

Проблематика. Ефективність інновацій, тенденції патентування нанотехнологій та рівень розвитку нанотехнологій в Україні головним чином визначаються кваліфікацією українських науковців. Тому проблеми збереження наукового потеціалу України та запобігання його відтоку за кордон є одними з найактуальніших на сьогодні.

Мета. Визначити роль наукових досліджень в економіці України та світу, рівень публікацій українських авторів, ефективність, патентний обіг та перспективи інновацій в Україні. Охарактеризувати світовий ринок нанотехнологій та рівень розвитку нанотехнологій в Україні та надати прогноз інноваційного розвитку в державі та світі.

Матеріали і методи. Використано статистичні дані наукового потенціалу України, кількості науково-дослідних робіт в Україні, матеріали щодо кількісного та якісного рівня наукових публікацій український авторів, патентного обігу, ефективності інновацій в Україні за період 2010-2017 рр. для прогнозування інноваційного розвитку в Україні та світі на найближчі десятиліття.

Результати. Зроблено оцінку наукового потенціалу України, сьогоднішнього рівня нанотехнологій, інновацій та тенденцій їхньго подальшого розвитку. Сформовано прогноз інноваційного розвитку в Україні та світі до 2030 року.

Висновки. Україна має потужний науковий потенціал, але рівень патентної та інноваційної активності в Україні низький. На фоні інтеграції українських науковців у світову спільноту спостерігається значне збільшення кількості спільних наукових публікацій українських науковців із закордонними колегами.

Ключові слова: інноваційна діяльність, патенти, нанотехнології, науково-дослідна робота. 